\title{
超塑性 $\mathrm{Zn}-22 \mathrm{wt} \% \mathrm{Al}$ 合金の盛り上げ変形挙動に 及ぼす超音波振動の影響*
}

\author{
松木 賢司**・高田 修一*** ・ 時沢 貢**
}

Effect of ultrasonic oscillations on behavior of close-die extrusion

of superplastic $\mathrm{Zn}-22 \mathrm{wt} \% \mathrm{Al}$ alloy*

UDG:669.45’71: 534.838

\author{
Kenji MATSUKI**, Shuichi TAKATA*** \\ and Mitsugu TOKIZAWA**
}

\begin{abstract}
Superplastic $\mathrm{Zn}-22 \mathrm{wt} \% \mathrm{Al}$ alloy was extruded by close-die sets with three types of punch to which ultrasonic oscillations are applicable. The extrusion load $(\mathrm{W})$ is related to the extrusion speed $(V)$ by the equation $W \propto V^{\mathrm{m}}$. The values of $\mathrm{m}$ " generally 0.4 to 0.5 are comparable to those of strain rate sensitivity index $\mathrm{m}$ in superplastic deformation in tension or compression. In the extrusion condition in which severe frictional restraint arrises, however, $\mathrm{m}^{\prime \prime}$ decreases down to 0.3 or less. If ultrasonic oscillations are applied, the extrusion load decreases, and $\mathrm{m}^{\prime \prime}$ does not decrease even in the extrusion condition described above. Application of ultrasonic oscillations is effective to flatten the top shape of specimens and to increase the extrusion speed at a constant load. The degree of extrusion load and increase of extrusion speed by applying ultrasonic oscillations are mainly due to the decrease of frictional constraint.
\end{abstract}

Key words: $\mathrm{Zn}-22 \mathrm{wt} \%$ alloy, superplasticity, close-die extrusion, ultrasonic oscillation, friction

(Received January 14, 1985)

\section{1. 緒言}

微細結晶粒超塑性合金は, 温度とひずみ速度が適切な 変形条件における伸び・延性が著しく大きく，しかも変 形中ほとんど加工硬化しない低流動応力状態を示す。こ の超塑性特性を板材やブロック材の塑性加工に応用し低 加工力で, 複雑形状部品の一工程成形, 固相接合と併用 した一体化加工，加工型面微細凹凸の精密転写などが可 能であるなど，加工事例も多く報告されている1)。一 方，その実施過程でいくつかの加工利用上の問題点も明 らかにされ，その対策が考えられている2)。それらの問 題点のうちには, 張り出し成形に打ける肉厚の不均一, 型なじみの不足, 焼付き, 離型時の材料変形等, 型と材 料間の摩擦が関係すると思われるものも多い。また型面 形状が複雑かつ微細なほど, 加工中摩擦の影響を受け易 く, 加工時間増大の原因になると考えられる。超塑性加 工にとつて加工時間の短縮は重要な課題である2)。適切
な潤滑剂の使用は摩擦力低減に役立つが, 型面微細部に 潤滑剂がたまる場合にはむしろ材料のなじみを阻害す $ろ^{3)}$ 。超塑性の優れた低流動応力特性を有効利用するた めの基礎研究の一環として, 超塑性変形においても摩擦 現象およびその低減の種々の検討が必要であろう。

著者らはこのような観点から, 前報 ${ }^{4)}$ で $\mathrm{Zn}-22 \% \mathrm{Al}$ 共 析合金の超塑性圧縮変形における摩擦現象を詳細に検討 し, 変形中の超音波振動の重盢は摩擦および変形応力の 低減に役立つこをを報告した。本研究では, 前回試作し た超音波付加試験装置を用いて超塑性 $\mathrm{Zn}-22 \% \mathrm{Al}$ 共析 合金の盛り上げ加工 ${ }^{5}$ )試験を行い，幅の狭い平行みぞや テーパみぞへの材料の盛り上り変形過程および充満性に およぼす超音波振動付加の効果を基礎的に検討した。本 実験の盛り上げ加工では，材料の盛り上り方向と工具振 動方向が平行かまたはそれに近いので, 塑性流動方向と 振動方向が直角な圧縮変形における結果4) と併せて，超 音波振動付加の効果を一層明確にできる。

* 超塑性変形挙動に及ぼす超音波振動付加の影響に関する研究 第 2 報

** 富山大学工学部 (富山市)。Faculty of Engineering, Toyama University (Toyama).

*** 富山大学大学院 (現(株)不二越)。Graduate School, Toyama University (now Fujikoshi, Ltd.). 


\section{2. 実験方法}

\section{1 試験片および試験装置}

本実験で使用した試験片の化学組成および作成手順は 前報 ${ }^{4)}$ と同様で, 試験片寸法は直径 $7.6 \mathrm{~mm}$, 高さ $8 \mathrm{~mm}$ である。盛り上げ加工試験に際しては, 前報で述べた超 音波付加圧縮試験装置の圧縮用ホーンを, 先端に盛り上 げ加工用ポンチ（直径 $7.6 \mathrm{~mm}$, 長さ $10 \mathrm{~mm}$ ) を一体化 加工した新たなホーン（段付きホーン）に取り換えた。 さらに圧縮受圧台上に, Fig. 1 に示したように, 子午面 で 2 分割できるダイをダイホルダーに組み込んで配置し た。このような盛り上げ加工装置の共振系はポンチ先端 までであり，共振系全体で 2 波長共振するように設計し た。前述した段付きホーンの振幅拡大率到は1.033であ り, その先端振幅 $(u)$ は, 超音波発振器出力電流が同 じならば前報の圧縮用ホーンの先端振幅にほぼ等しい。

盛り上げ加工試験のポンチ形状は 3 種類とし, その詳 細形状を試験片およびダイの配置と共に Fig. 2 に示し た。クロスヘッドの下降に伴い, ポンチーA では中央の 幅 $1 \mathrm{~mm}$ の平行みぞへ, そしてポンチーB, - $\mathrm{C}$ ではポ ンチとダイ間のリング状の平行みぞとテーパみぞへ材料 が盛り上り変形する。ポンチーA の平行みぞの底部は, 工作手法上平らにできなかつたが，ポンチーB とーC で はいずれも鋭い底部形状となつている。

\section{2 盛り上げ加工試験方法}

試験温度はダイホルダーに取り付けた熱電対で検出し

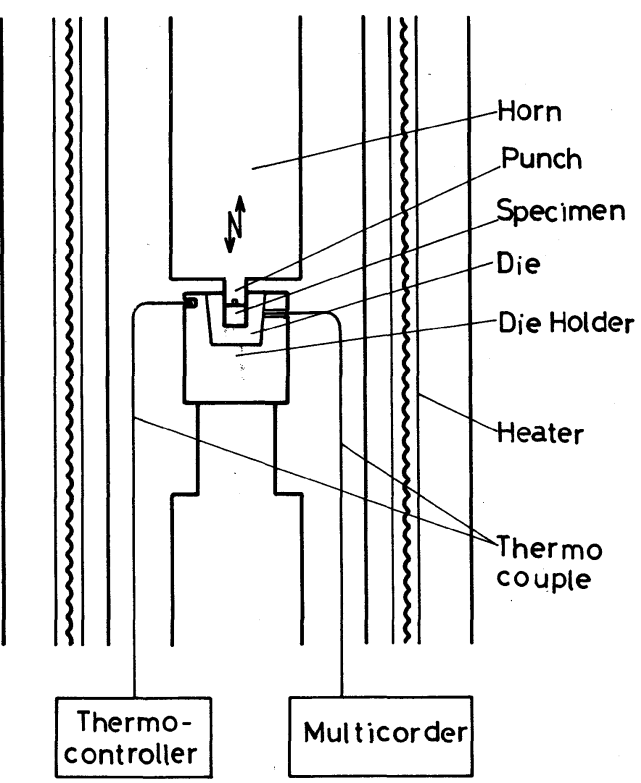

Fig. 1 Main part of the testing apparatus for superimposition of ultrasonic oscillation.

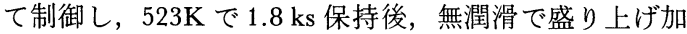
工試験を開始した。その際の荷重 $(W)$ の変化は圧縮受 圧台下部のロードセルで検出しマルチコーダで記録し た。ただし, 本試験装置の許容負荷が小さいため, 種々 のクロスヘッド速度 $(V)$ で試験を開始後, 最大荷重 $\left(W_{\max }\right) 2.94 \mathrm{kN}$ に達した直後停止する最大荷重試験と, 各種のクロスヘッド速度で試験を開始し，所定の保持荷 重 ( $\left.W_{\text {hold }}\right)$ に達した後はクロスヘッドの下降と停止を繰 り返して荷重を $W_{\text {hold }} \pm 0.1 \mathrm{kN}$ で一定時間保持する定荷 重保持試験の 2 種類の試験を行つた。両試験の詳細な条 件を Table 1 に示した。定荷重保持試験では，クロスへ ッド停止中にクリープ変形が進行して荷重が徐々に減少

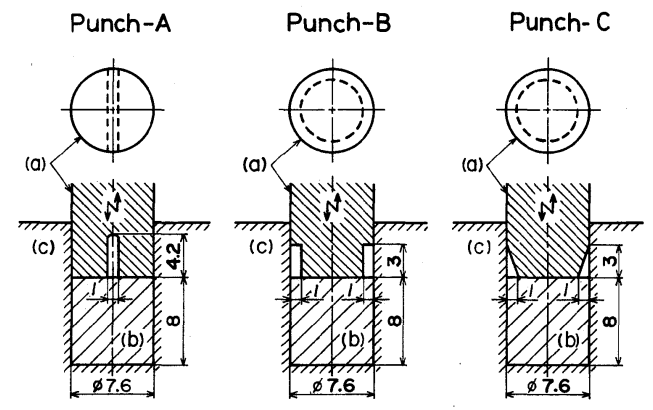

Fig. 2 Schematic diagrams of three types of close-die extrusion tool. (a) Punch, (b) Specimen, (c) Die.

Table 1(a) Maximum load test conditions

\begin{tabular}{l|c|c|c}
\hline \hline & Punch-A & Punch-B & Punch-C \\
\hline $\begin{array}{c}\text { Maximum Load } \\
\mathrm{W}_{\text {max }}(\mathrm{kN})\end{array}$ & \multicolumn{3}{|c}{2.9} \\
\hline $\begin{array}{c}\text { Crosshead Speed } \\
\mathrm{V}\left(10^{-3} \mathrm{~mm} / \mathrm{s}\right)\end{array}$ & $1.7-8.3$ & $5-33$ & $1.7-25$ \\
\hline $\begin{array}{c}\text { Temperature } \\
\mathrm{T}\end{array}$ & \multicolumn{3}{|c}{523} \\
\hline $\begin{array}{c}\text { Amplitude } \\
\mathrm{u}\end{array}$ & \multicolumn{3}{|c}{$0,3.5$} \\
\hline
\end{tabular}

Table 1(b) Constant load test conditions

\begin{tabular}{l|c|c|c}
\hline \hline & Punch-A & Punch-B & Punch-C \\
\hline $\begin{array}{l}\text { Constant Load } \\
\mathrm{W}_{\text {hold }}(\mathrm{kN})\end{array}$ & $2.9 \pm 0.1$ & $2.0 \pm 0.1$ & $2.9 \pm 0.1$ \\
\hline $\begin{array}{c}\text { Crosshead Speed } \\
\mathrm{V}\end{array}$ & 6.7 & 17 & 17 \\
\hline $\begin{array}{c}\text { Forming Time } \\
\mathrm{t}\end{array}$ & $0.3-1.5$ & $0.12-0.6$ & $0.12-0.6$ \\
\hline $\begin{array}{c}\text { Temperature } \\
\mathrm{T}\end{array}$ & \multicolumn{3}{|c}{523} \\
\hline $\begin{array}{l}\text { Amplitude } \\
\mathrm{u}\end{array}$ & \multicolumn{3}{|c}{$0,3.5$} \\
\hline
\end{tabular}


するが，ダイみぞへ材料が充満すると荷重が減少しなく なるので, この状態を充満完了の目安にして試験を停止 した。

盛り上げ加工試験を停止後ダイから取り出した試験片 の盛り上り形状の寸法は, 傾角顕微鏡（ユニオン光学 製，読取精度 $1 / 100 \mathrm{~mm}$ ）を使用して精密に測定した。

\section{3. 実験結果および考察}

\section{1 盛り上げ加工荷重一クロスヘッド ストローク 線図}

Table 1(a) に示した範囲のクロスヘッド速度で $W_{\max }$ $=2.94 \mathrm{kN}$ に達するまでの最大荷重試験を行い, 盛り上 げ加工荷重 $(W)$ 一クロスヘッドストローク $(S)$ の関 係を最初に測定した。Fig. 3(a)，(b) および(c)に，そ れぞれポンチーA, -Bおよび-C の結果を例示した。Fig. $3(\mathrm{a})$ ，(b)および(c)には，超音波振動無付加（ $u=0 ）$ と 付加（ $\mathrm{u}=3.5 \mu \mathrm{m} ）$ 時の $W-S$ 線図をそれぞれ点線と実線 で示し，またそれぞれのダイみぞを材料がほぼ充満完了 する $S$ を横軸に矢印で示した。Fig. 3(a), (b) および(c) から， 3 種類のポンチにおいて， $V$ が増大寸ると $W$ は 大きくなり，超音波振動の付加は $W$ を減少させること が明らかである。Fig. 3(a) と（b)に示した $W-S$ 線図に は，一般にストロークの増大に伴い，盛り上り変形初期 に荷重が急増した後（第 1 領域）, 定常あるいはやや減 少状態を示し（第 2 領域），その後再び急増する（第 3 領域）傾向がある。一定クロスヘッド速度で比較する と，超音波振動を付加することによつて，特に第 2 領域 の荷重の減少が明りようで， $W_{\max }$ に達するまでにスト
ロークが著しく大きくなる場合があつた。このような場 合には試験片の盛り上り高さが著しく増加する。

次に, Fig. 3 のような $W-S$ 線図を測定後，ダイから 取り出した各試験片の盛り上り高さと $S$ の関係を測定し,

Fig. 4 に示した。Fig. 4 では，ポンチ-A, -Bおよび-C による各試験片の盛り上り部のうち，ダイと接触してい た高さの最小值をそれぞれ $h a, h b$ および $h c$ とした。 Fig. 4 に示したように，3種類のポンチによる盛り上り 高さとストロークの関係はほぼ直線で整理できる。これ らの直線の内捙から, 盛り上り変形を開始するストロー クは，各ポンチでおおよそ $0.4 \sim 0.5 \mathrm{~mm}$ の範囲にある ことが分かる。この值は, Fig. 3(a)と（b)に示した $W-S$ 線図の第 1 領域から第 2 領域へ変化するストロークに比 較的近い。上野ら ${ }^{7)}$ は，超塑性 Zn-22\%Al 合金を乾性弗 素潤滑剤を使用してホビング加工すると，平均ホビング

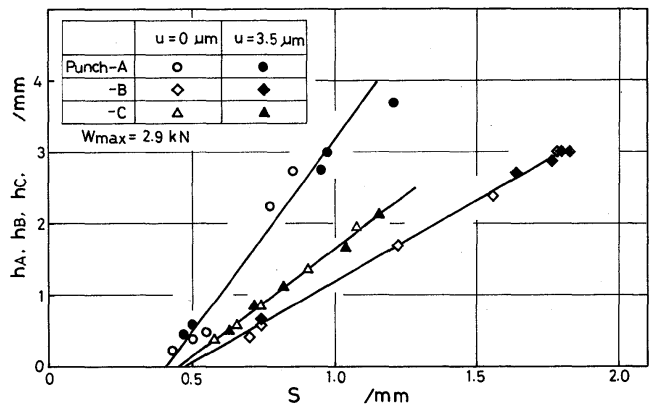

Fig. 4 Change of extrusion web hights with crosshead stroke.
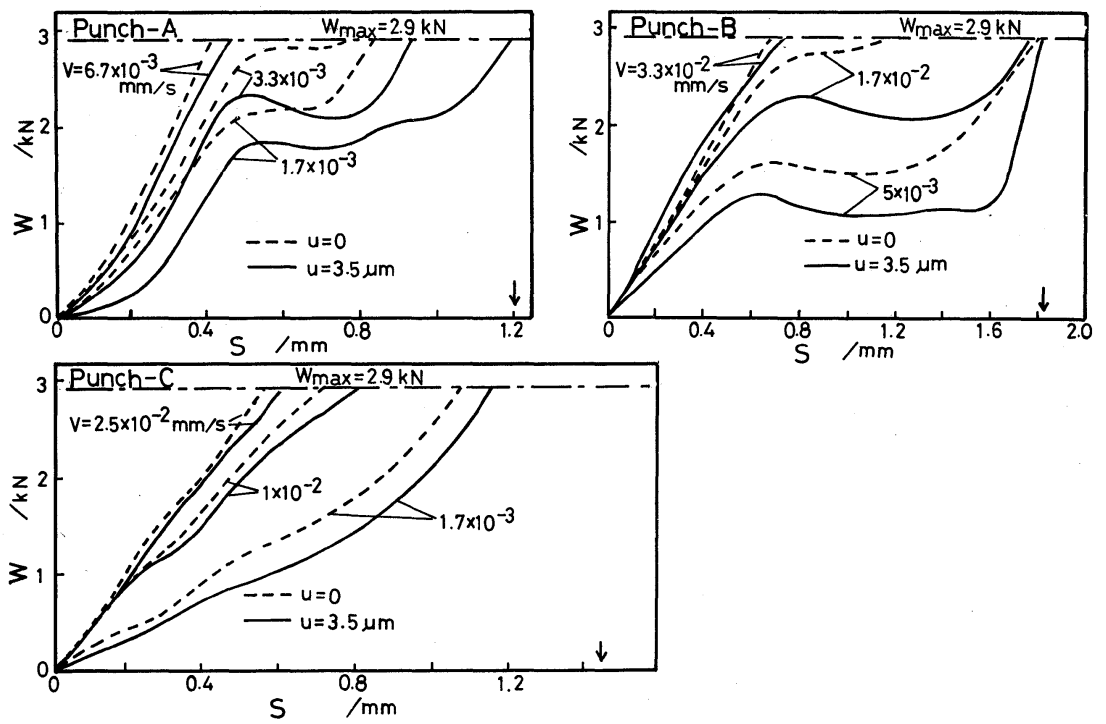

Fig. 3 Change of load $(W)$ vs. crosshead stroke $(S)$ curves with crosshead speed $(V)$. (a) Punch-A, (b) Punch-B, (c) Punch-C. 
圧力がある押込み深さ以上でほぼ一定となり，この付近 を境として变形様式が押込みの非定常変形から後方押出 しの定常変形に移り変わると述べている。

本実験における Fig. 3(a)と(b)の第 1 領域から第 2 領 域への移行も, 試験片とダイの間吵を埋めるすえ込み変 形を含めた非定常变形から盛り上りの定常变形へ移る変 化に対応していると思われる。一方，本実験は無潤滑で 実施しているから, 盛り上り变形の進行による摩擦面積 の増加，あるいは変形後期のダイみぞのすみ角を満たす 段階で摩擦抵抗が著しく増した時に第 3 領域へ変化す る。ポンチ-C を使用した場合には，盛り上り変形開始 後すぐに，上述したすみ角を満たすのと似た変形になる ため第 2 領域が明りようではない。

一般に超塑性変形においては, 流動応力 $(\sigma)$ のひず み速度 $(\dot{\varepsilon})$ 依存性が大きい特徵があり, その依存性指数 $m\left(\sigma=K \dot{\varepsilon}^{m}\right)$ が0.3〜 1.0の範囲の高い值をとることが超 塑性変形の指標にされている8 したホビング加工において，平均ホビング圧力 $(\bar{P})$ と 押込み速度 $(V h)$ の間に次の関係を見いだした。

$$
\bar{P}=K V h^{m^{\prime}}
$$

ここで $K$ と $m^{\prime}$ は温度をパラメータとする定数である。 そして各温度における $m^{\prime}$ は圧縮試験で得られた $m$ とほ ぼ一致し， $523 \mathrm{~K}$ では $m^{\prime}=0.41$ になることを報告した。

そこで本実験においても，盛り上げ加工荷重 $(W)$ と 盛り上げ加工速度すなわちクロスヘッド速度 $(V)$ の関 係を明らかにし，それに対する超音波振動付加の影響に ついても検討した。Fig. 5 に，ポンチ-A とポンチ-Bの $W-S$ 線図の第 2 領域（Fig. 3(a) と（b)参照）に含まれる 各一定の $S$ の值において,$W$ と $V$ の関係を両対数で整 理した。本実験の範囲内において，ポンチ-A と-Bの

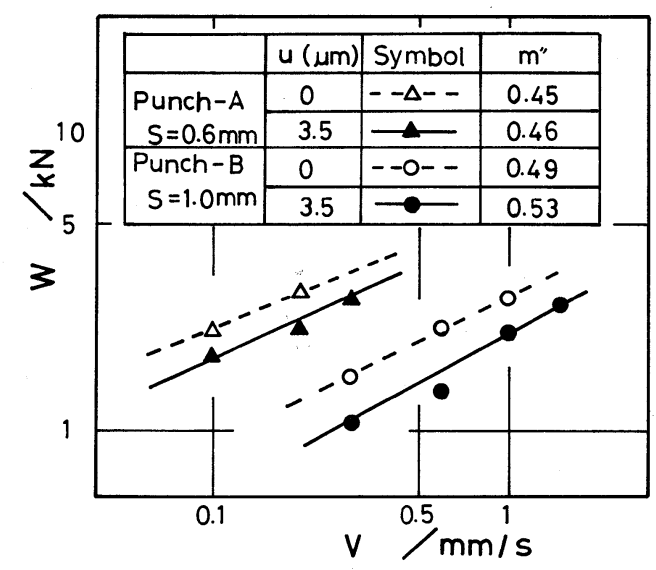

Fig. 5 Dependence of extrusion load $(W)$ on crosshead speed $(V)$ in the extrusion tests used punch-A and Punch-B, respectively, with or without ultrasonic oscillation.
$W$ と $V$ の間には，いずれもほぼ直線関係が認められる。 すなわち，Wと $V$ の間には(1)式におけると同様の関係 が存在する。ただ，それらの直線の勾配から求めた，W の $V$ 依存性指数 $m$ " の值に対する超音波振動付加の影響 は小さく, Fig. 5 に示したようにポンチ-A では約 0.45 , そしてポンチ-Bでは0.5に近い值になつた。これらの值 は，いずれも超塑性変形状態に対応した值と考えられ

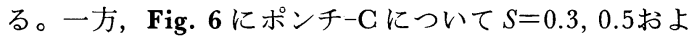
び $0.7 \mathrm{~mm}$ での $W$ と $V$ 関係を Fig. 5 と同様に整理し た。その結果，ポンチ-Cについても各条件の $W$ と $V$ の間には直線関係がある。それらの直線の勾配から求め た $m^{\prime \prime}$ の値を比較すると, $\mathrm{u}=0$ の場合 $S=0.3 \mathrm{~mm}$ では $m^{\prime \prime} \simeq 0.45$ で比較的高い值を示したが， $S$ の増大によつて 減少する傾向があり $S=0.7 \mathrm{~mm}$ では $m^{\prime \prime} \simeq 0.29$ になつ た。しかし $\mathrm{u}=3.5 \mu \mathrm{m}$ の場合, $S$ の増大に伴う $m^{\prime \prime}$ の減 少はわずかで, $S=0.7 \mathrm{~mm}$ においても $m^{\prime \prime} \simeq 0.42$ であつ た。ポンチ-Cによる盛り上げ变形では, Fig. 3 に関し て述べたように，ポンチ-A と-B の第 3 領域における ような変形が起ると考えられる。したがつて, 以上の結 果から，ダイみぞのすみ角を材料が充満するような，特 に摩擦拘束の著しく増大する変形段階では, 超塑性が抑 制されるが，超音波振動の付加はその抑制を緩和するの に有効であることが明らかである。

\section{2 盛り上り形状}

3.1 で述べた結果にもとづき，ここで述べる定荷重保 持試験では，ポンチ-A と-B の保持荷重がいずれも第 1 領域に含まれるような $V$ を選び, 荷重保持中の盛り上

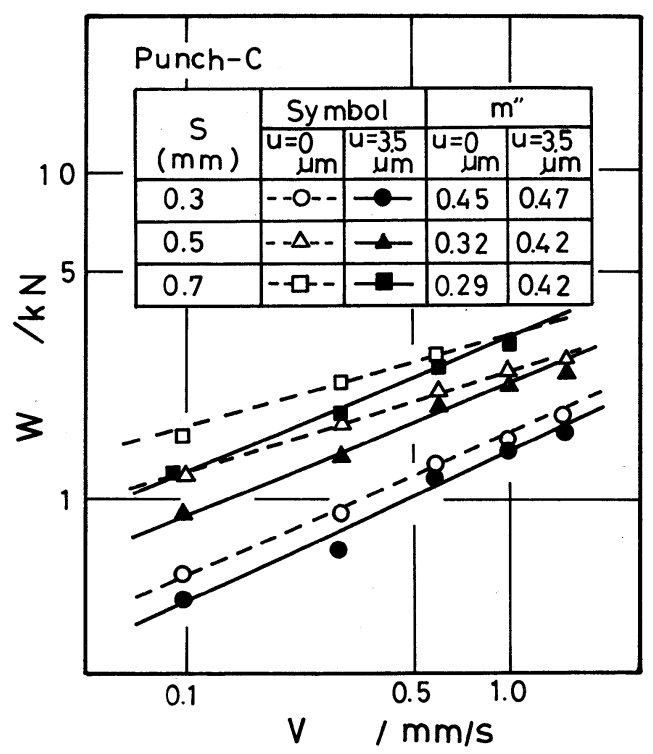

Fig. 6 Dependence of extrusion load $(W)$ on crosshead speed $(V)$ in the extrusion tests used punch-C with or without ultrasonic oscillation. 


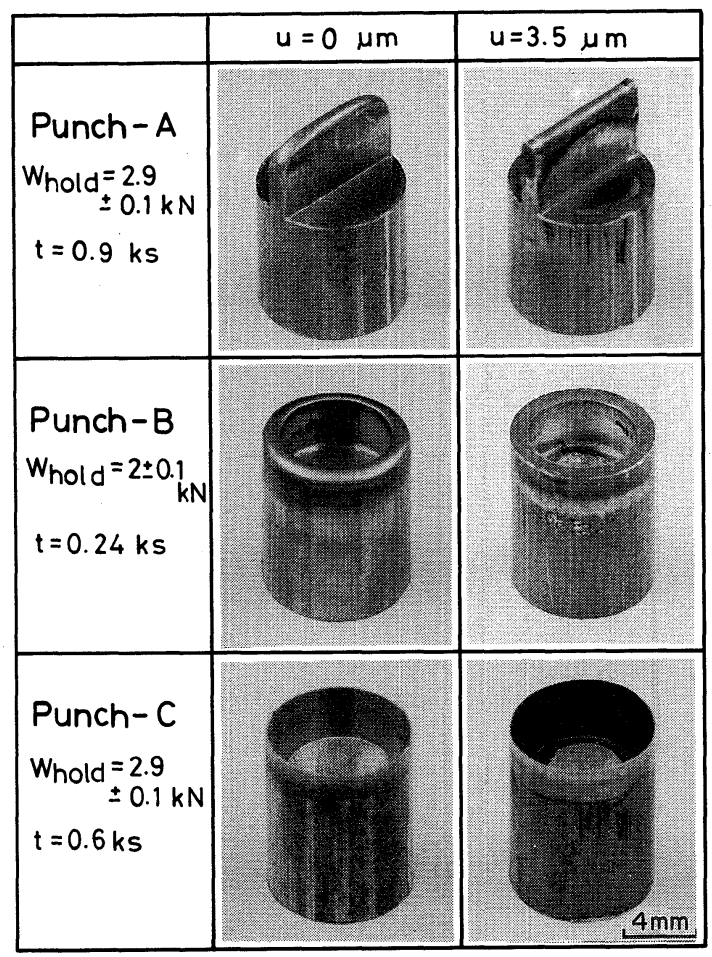

Fig. 7 Comparison of specimen shapes extruded at constant loads by using of punch-A, $-\mathrm{B}$, and $-\mathrm{C}$, respectively, with or without ultrasonic oscillation.

り变形に対する超音波振動付加の効果を検討した。すな わち, Table 1(b)に示した条件の定荷重保持試験を 3 種 類のポンチを使用して実施した。Fig. 7 に, ダイから取 り出した試験片の盛り上り形状の例を示した。Fig. 7 に おいて, 同一加工条件であつても, 超音波振動無付加 $(\mathrm{u}=0)$ と付加 $(\mathrm{u}=3.5 \mu \mathrm{m})$ では, 試験片の盛り上り 高さと先端形状に明りような相違がある。ポンチ-A と$\mathrm{B}$ では, $\mathrm{u}=0$ の場合ダイみぞのすみ部付近の材料の盛 り上りが遅れ充満が不充分であるにもかかわらず， $\mathrm{u}=3.5 \mu \mathrm{m}$ では促進されたことが分かる。ポンチ-Cで は, $\mathrm{u}=0$ の場合でもダイみぞのかなり幅の狭い高さ位 置まで盛り上り変形しているが, $u=3.5 \mu \mathrm{m}$ では一層鋭 い先端形状が得られた。

つぎに，3種類のポンチを用い種々の保持時間で定荷 重保持試験を中断し, ダイから取り出した各試験片の盛 り上り部断面形状を精密に測定した。ポンチーAによる 試験片の測定個所は, 盛り上り部板面に平行な中心軸断 面と直角な中心軸断面とし，ポンチ-B と-C による試験 片に関しては最も盛り上り高さの小さい中心軸断面とし

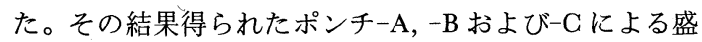
り上り形状と盛り上り速度におよぼす超音波振動付加の 影響をそれぞれFig. 8, Fig. 9 およびFig. 10に示した。

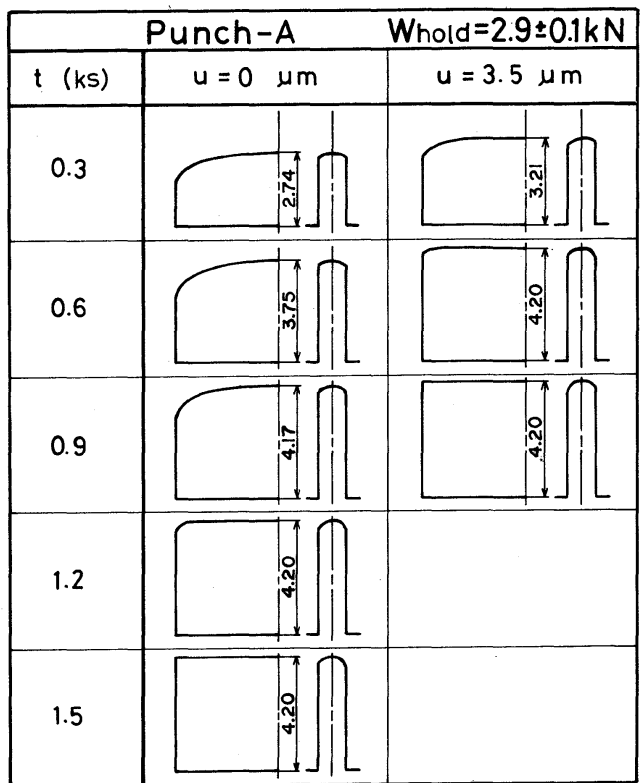

Fig. 8 Effect of deformation time $(t)$ and application of ultrasonic oscillation on longitudinal section shape of webs extruded at constant load $\left(W_{\text {hold }}=2.9\right.$ $\pm 0.1 \mathrm{kN}$ ) with punch-A.

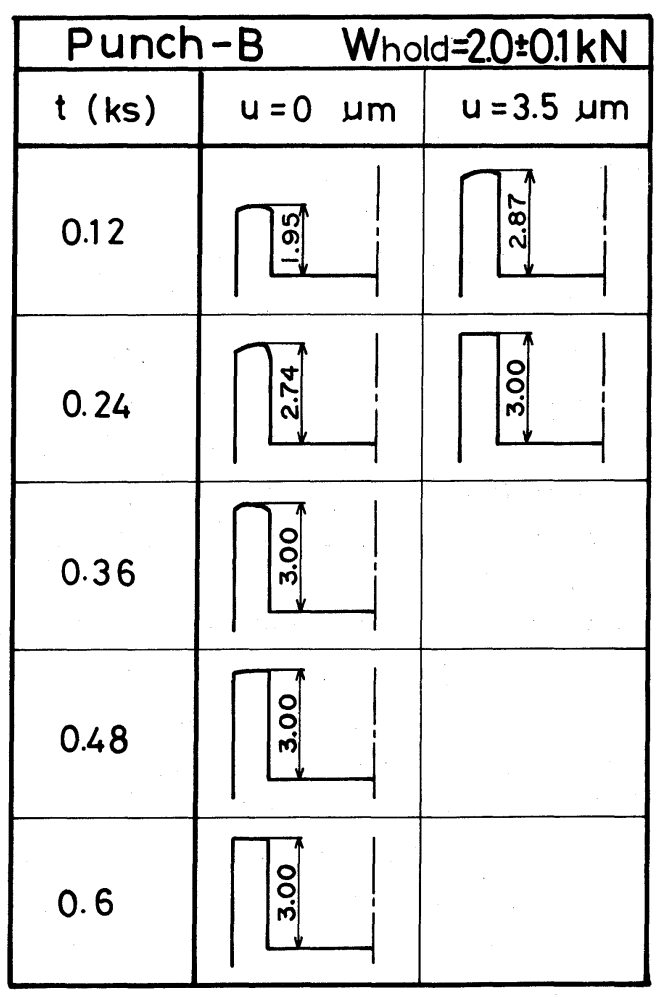

Fig. 9 Effect of deformation time $(t)$ and application of ultrasonic oscillation on longitudinal section shape of webs extruded at constant load ( $W_{\text {hold }}=2.0$ $\pm 0.1 \mathrm{kN}$ ) with punch-B. 


\begin{tabular}{|c|c|c|}
\hline \multicolumn{3}{|c|}{ Punch-C } \\
\hline$t(k s)$ & $u=0 \mu \mathrm{m}$ & $\mathrm{u}=3.5 \mu \mathrm{m}$ \\
\hline 0.12 & & गู \\
\hline 0.24 & & \\
\hline 0.36 & & \\
\hline 0.48 & & \\
\hline 0.6 & ( & ה. \\
\hline
\end{tabular}

Fig. 10 Effect of deformation time $(t)$ and application of ultrasonic oscillation on longitudinal section shape of webs extruded at constant load ( $W_{\text {hold }}=2.9$ $\pm 0.1 \mathrm{kN}$ ) with punch-C.

各図中には試験片断面の中心軸を一点鎖線で示し，ま た各試験片断面の最大盛り上り高さを記入した。Fig. 8 において, 盛り上り部板面に平行な中心軸断面 (左側) を各保持時間 $(\mathrm{ks})$ で比較すると, $\mathrm{u}=0$ の場合には中 心軸寄りの盛り上り变形が先行し側面付近で遅れるが, $\mathrm{u}=3.5 \mu \mathrm{m}$ では比較的均一な盛り上り形態を示しダイへ の充満を短時間で完了した。Fig. 9 に示したポンチ-B に関する結果からも， $\mathrm{u}=3.5 \mu \mathrm{m}$ の方が著しく盛り上り 変形が促進されたことが分かる。Fig. 8 と Fig. 9 から $\mathrm{u}=3.5 \mu \mathrm{m}$ の超音波振動を付加することによつて，ダイ みぞに材料が充満完了する時間はポンチ-A では約 $40 \%$, ポンチ-Bでは約 $60 \%$ 短縮されたことが明らかである。 この傾向は超音波振動振幅が増大寸れば一層顕著になる と思われる。一方, Fig. 10からポンチ-Cにおいても超 音波振動付加の効果が明りようで鋭い先端形状が得られ た。そこで, Fig. 10の測定に用いた各試験片の盛り上 り先端の幅 $\mathrm{b}$ と保持時間 $\mathrm{t}$ の関係におよぼす超音波振動 付加の影響を Fig. 11に示した。Fig. 11に扔いて，u=0 では $\mathrm{b}=0.2 \mathrm{~mm}$ となるのに約 $0.48 \mathrm{ks}$ 要し, $2.94 \pm 0.1$ $\mathrm{kN}$ の保持荷重では $\mathrm{b}$ はそれ以下に減少しにくいようで

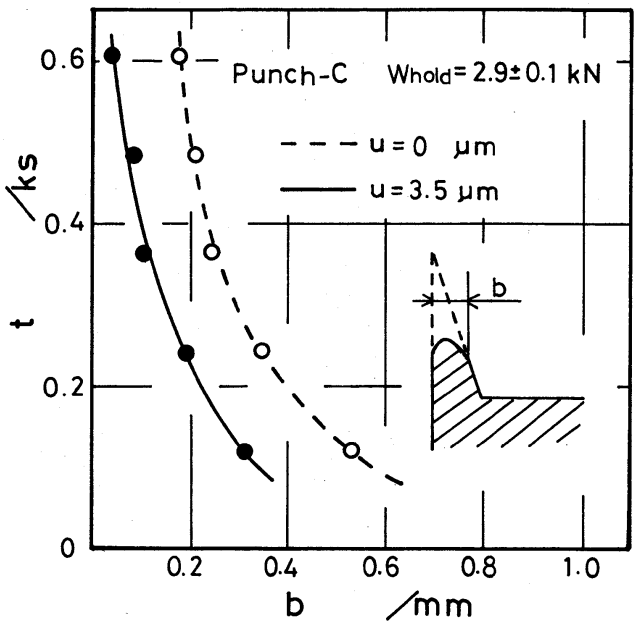

Fig. 11 Effect of superimposed ultrasonic oscillation on the relationship between deformation time and top width of web (b) extruded at constant load ( $W_{\text {hold }}=2.9 \pm 0.1 \mathrm{kN}$ ) with punch-C.

ある。しかし， $\mathrm{u}=3.5 \mu \mathrm{m}$ では約 $0.24 \mathrm{ks}$ で $\mathrm{b} \simeq 0.2 \mathrm{~mm}$ となり，0.6 ks 後には $\mathrm{b} \simeq 0.04 \mathrm{~mm}$ となつた。すなわ ち, 超音波振動付加によつてダイの細部への充満性が著 しく向上した。

つぎに, ポンチ-B と-C では盛り上り変形中の材料 は, 静止したダイと下降するポンチの, 両側で異なつた 摩擦面に接するから，盛り上り先端形状はその影響を反 映するはずである。ポンチ- $\mathrm{C}$ ではその形状の影響も加 わる。このような観点から，ポンチーB と-Cによる盛り 上り先端形状を詳細に検討し，その結果をそれぞれ

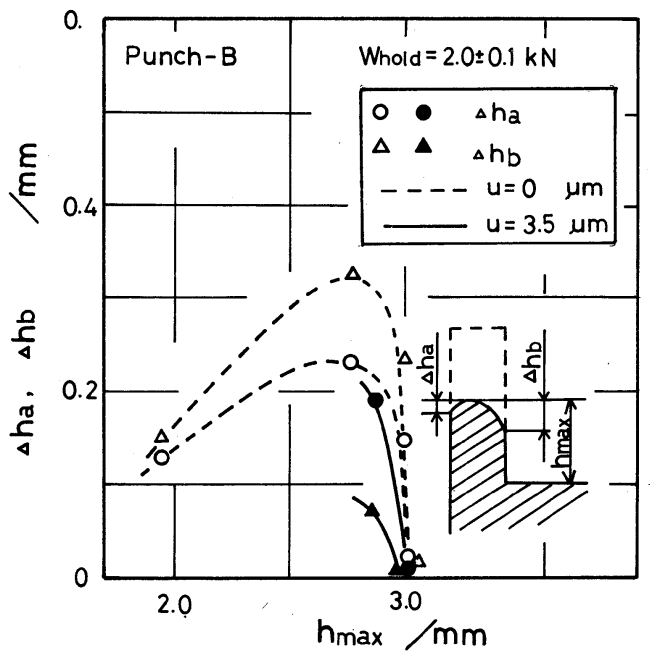

Fig. 12 Effect of superimposed ultrasonic oscillation on top shape of webs extruded at constant load ( $W_{\text {hold }}=2.0 \pm 0.1 \mathrm{kN}$ ) with punch-B. 


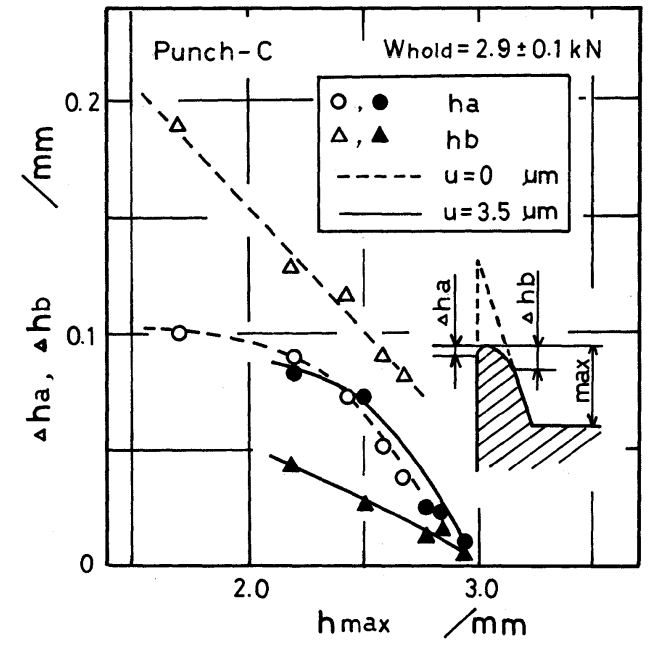

Fig. 13 Effect of superimposed ultrasonic oscillation on top shape of webs extruded at constant load ( $W_{\text {hold }}=2.9 \pm 0.1 \mathrm{kN}$ ) with punch-C.

Fig. 12と Fig. 13に示した。各図中に示したように，各 変形時間における盛り上り部の最大高さを $h_{\max }$ とし， $h_{\max }$ からダイおよびポンチに接触した盛り上り部の高さ を差引いた值をそれぞれ $\Delta h a$ および $\Delta h b$ とし，相互の 関係を整理した。Fig. 12およびFig. 13において，それ ぞれ各一定の $h_{\max }$ で比較すると, $\mathrm{u}=0$ では $\Delta h a よ り$ $\Delta h b$ が大きい。すなわち, ポンチ側面ではダイ側面より 盛り上り変形が抑制されている。しかし， $\mathrm{u}=3.5 \mu \mathrm{m}$ で はポンチ-B と-Cにおいて $\mathrm{u}=0$ の場合より $\Delta h b$ が著 しく減少した。このような $\Delta h b$ の減少はポンチの超音 波振動によつて，その界面の摩擦拘束力が緩和されたた めと理解できる。一方, Fig. 12と Fig. 13において超音 波振動の付加によつて $\Delta h a$ がほとんど変化しなかつた のは, 試験片内部への振動伝達が少なかつたためであろ う。

本実験で得られた超音波振動の効果は, 摩擦拘束力の 低下が主な原因と考えられる。

\section{4. 結言}

超塑性 Zn-22 wt\%Al 合金の盛り上げ加工試験を， 3
種類のみぞ形状の密閉型を使用して実施した。そして， 材料の盛り上り時間や盛り上り形状におよぼす超音波振 動付加（振動振幅 : $3.5 \mu \mathrm{m}$ ）の影響を検討した。得られ た結果を要約すると次の通りである。

1）盛り上げ加工荷重は, 超音波振動の付加によつて 減少した。

2）加工速度 $(V)$ と盛り上げ加工荷重 $(W)$ の間には, $W \propto V^{m}$ の関係が認められ，一般に $\mathrm{m}^{\prime \prime}=0.4 \sim 0.5$ の值 を示した。この値は, 本合金の超塑性引張または圧縮変 形で求められているひずみ速度感受性指数 $m$ 值にほぼ 近い。ただ，摩擦拘束力が著しく增大する加工条件では $m^{\prime \prime}$ は0.3以下に減少したが, 超音波振動を付加した場合 にはほとんど減少しなかつた。

3）超音波振動付加によつて, 試験片の盛り上り先端 形状が平坦化し, 一定荷重下では盛り上り速度が増大し た。

4）盛り上り先端形状および $m$ ” の測定結果に基づけ ば, 上述した超音波振動の効果は主に摩擦拘束力の減少 によると考えられた。

終りに, 卒業研究として本実験に協力された木村修君 (現在 : (侏)不二越), 中井裕二君 (現在 : ゴールドウィン (株)）に深く感謝致します。また研究費の一部は文部省科 学研究費 (一般研究(c)) によつた。付記して謝意を表 します。

\section{参考文献}

1）例えば，超塑性研究会編：超塑性の利用開発に関す る研究 · 調査 · I , (1981). II , (1982). III, (1983). IV, (1984).

2) 小林: 機械の研究, 29 (1977), 1406.

3) E. G. Thomsen, C. T. Yang and S. Kobayashi 著, 工 藤訳 : 金属塑性加工の力学, p. 380, コロナ社.

4）松木, 高田, 時沢 : 軽金属学会投稿中.

5）大下, 武井, 山根：日本金属学会誌, 39 (1975), 98.

6）島川：超音波工学, p. 118, 工業調査会.

7）上野, 宮川, 篠原, 諸星 : 塑性と加工, 16（1975）, 914.

8）松木 : 機能性アルミニウム材料, 軽金属学会第21回 シンポジウム, p. 10 . 